\title{
THEORIES OF ETHNICITY, NATIONALITY AND ETHNIC IDENTITY
}

\author{
'D.S. Kaliyev, ${ }^{2}$ Aimar Ventsel
}

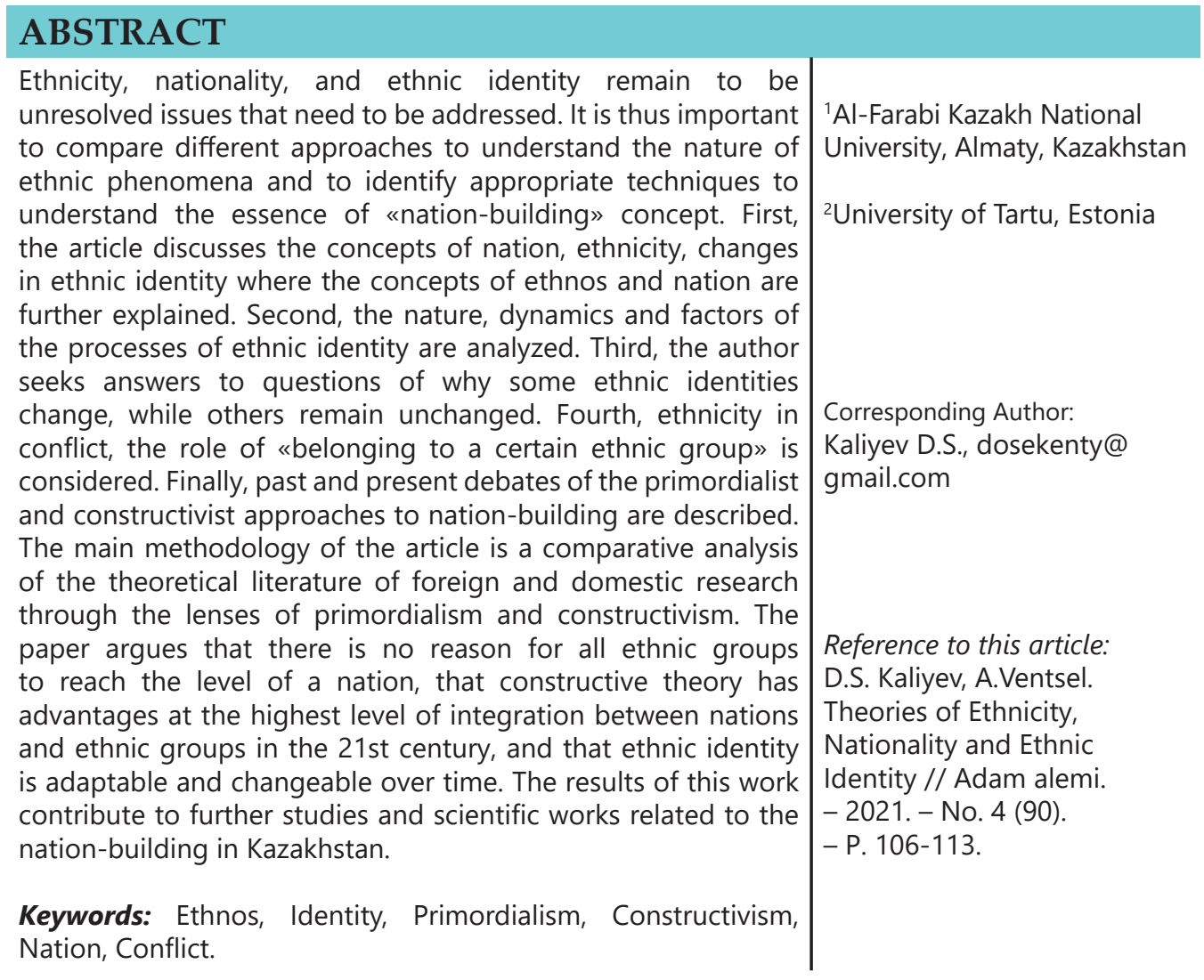

\section{Этнос, ұлт, этникалық бірегейлік теориялары}

Аннотация. Этнос, ұлт, этникалық бірегейлік мәселелері сұрақ туындатқан өз шешімін таппаған, бірінші кезектегі тақырып болып саналады. Сондықтан этникалық құбылыстардың табиғатын түсінудің әртүрлі тәсілдерін салыстыру және «ұлт құрылысы» құбылысының мәніне тиісті көзқарастарды анықтау маңызды болып табылады. Мақалада ұлт, этнос (ethnicity) ұғымдары, этникалық бірегейліктің өзгеру мәселесі талқыланды. Этнос пен ұлт ұғымдарына түсініктеме беріледі. Этникалық бірегейлік процестерінің табиғаты, динамикасы және факторлары талданады. Неліктен кейбір этникалық бірегейлік өзгереді, ал басқалары өзгермей тұрақты болып қалады деген сұраққа автор жауап іздейді. Қақтығыстағы этника (ethnicity), «белгілі этникалық топқа жату» рөлі қарастырылады. Ұлт құрылысында примордиалистік және конструктивистік көзқарастың өткен және қазіргі пікірталастары талқыланып жүрген тұстары сипатталады. Мақаланың негізгі әдіснамасы шетелдік және отандық зерттеулердің теориялық әдебиеттерін салыстырмалы талдау болып табылады. Сонымен қатар примордиа- 
лизм мен конструктивизм ұғымдарына байланысты сипаттамалық әдіс қолданылады. Зерттеу нәтижесінде автор барлық этностар ұлт дәрежесіне жете алатындығына негіз жоқ екендігін, XXI ғасырда ұлт пен этникалық топтар арасындағы интеграцияның ең жоғары деңгейі кезінде конструктивистік теорияның артықшылықтарға ие болатындығын, этникалық бірегейлік бейімделгіш және өзгертілуі мүмкін екендігі, саяси элиталардың түрлі этностарды біріктіруге тырысқанымен, этникалық бірегейліктің рөлін төмендете алмайтындығы анықталды. Жұмыстың нәтижесінде алынған тұжырымдар мен қорытындылар Қазақстандағы ұлт құрылысына байланысты ғылыми жұмыстардың жазылуына және оны әрі қарай зерттелуіне септігін тигізеді.

Түйін сөздер: Этнос, бірегейлік, примордиализм, конструктивизм, ұлт, қақтығыс.

\section{Теории этноса, нации, этнической идентичности}

Аннотация. Этническая принадлежность, национальность и этническая идентичность остаются нерешенными вопросами, которые необходимо решить. Поэтому важно сравнить различные подходы для понимания природы этнических явлений и определить соответствующие методы для понимания сути концепции «национального строительства». Во-первых, в статье рассматриваются понятия нации, этнической принадлежности, изменения в этнической идентичности, где дополнительно разъясняются понятия этноса и нации. Во-вторых, анализируются природа, динамика и факторы процессов этнической идентичности. В-третьих, автор ищет ответы на вопросы о том, почему одни этнические идентичности меняются, в то время как другие остаются неизменными. В-четвертых, этническая принадлежность в конфликте, рассматривается роль «принадлежности к определенной этнической группе». Наконец, описываются прошлые и нынешние дебаты о примордиалистском и конструктивистском подходах к государственному строительству. Основной методологией статьи является сравнительный анализ теоретической литературы зарубежных и отечественных исследований через призму примордиализма и конструктивизма. В статье утверждается, что нет причин для того, чтобы все этнические группы достигли уровня нации, что конструктивная теория имеет преимущества на самом высоком уровне интеграции между нациями и этническими группами в 21 веке, и что этническая идентичность может адаптироваться и изменяться с течением времени. Результаты этой работы способствуют дальнейшим исследованиям и научным работам, связанным с нациестроительством в Казахстане

Ключевые слова: Этнос, идентичность, примордиализм, конструктивизм, нация, конфликт.

\section{Introduction}

First, the main idea of the article is to address the unresolved issues of ethnicity and nationality. Then the directions of primordialism and constructivism in the nation-building, the concept of ethnicity are discussed. In scientific terms, these two areas differ radically from each other. While primordialism interprets the concept of nation and ethnos from the beginning as a community of people with an unchanging biological kinship, the constructivist approach interprets ethnos as a "construct" that can be created as a result of the actions of individuals or elites in nation-building. Why do some ethnic identities seem to change, while others remain static? The issues of the role of the state in the change of unity, assimilation, what can hinder the unity of ethnic groups are covered. We will also look at the role of ethnicity in conflict. Origin of concepts, their development, evolution, used in dialectical and general methods. Political science and integrative methods are also used. A comparative analysis is conducted based on the use of theoretical literature of foreign and domestic research. The specifics of the article were presented in the form of a review of the works of scientific researchers of Ethnos, ethnicity, primordialism, constructivism, problems and directions of changes in ethnic identity. 


\section{Methodology}

The emergence of concepts, their development, evolution are used in dialectical and general methods. Political science and integrative methods are also used. A comparative analysis is carried out based on the use of theoretical literature of foreign and domestic research.

\section{Ethnic Identity Theory}

First of all we need to clarify the meaning of the term 'ethnicity'. Despite its relative novelty, ethnicity is a slippery term that has multiple and contested definitions, and, as Hale [1] opined, we are in the beginning phase of understanding this phenomenon. The existing literature differently conceptualizes ethnicity emphasizing the cultural, social, biological and other attributes of it. Some authors [2] characterize ethnic groups as the emotion-laden, multidimensional, fluid and organic entities. Others describe them as relatively stable kin groups tied with symbols [3]. For some scholars the ethnic groups are internally and externally changeable cultural and social constructs [4].

Ethnicity is an ambivalent term from the historical perspective. Some modernist scholars [5] conclude that the nation replaced ethnicity as an influential form of collective identity, while other authors consider ethnicity as a form of pre-modern cultural and social groups, which were subsequently transformed to nations as a result of the industrial revolutions $[3 ; 6]$. According to this logic, ethnicity should become an archaism after the birth of European nationalism in the 18th century with the creation of centralized nation-states. However, the main scientific debates on ethnicity sparked in the 20th century after the Second World War and are continued nowadays. The weakness of this concept is visible from the public debates occurring in almost all of the new independent countries with the multicultural populations, where the ethnic consciousness prevails the other forms of identities.

The main reason for the revival of the concept of ethnicity is that not all the ethnic became nations. Those "unsuccessful nationalisms" [7] who couldn't develop to the level of nations live under the alien states, and do not represent their own nations. Our goal is to figure out the place of the centralized Kazakhstani nation in the minds and hearts of the "successful" (ethnic groups with historical homeland) and "unsuccessful" (ethnic groups without state) nations.

As the aim of this work was to analyse the place of Russian ethnic minority in the new Kazakhstani nation, for us it is important to make a terminological clarification of "nation" and "ethnicity". Tishkov puts ethnic entity against polity (state) describing the nation as a place where these two forms of social groupings struggle for "their exclusive property" $[8$, p. 625]. For Hutchinson the ethnicity, maintained by the legends of common ancestry, shared past and distinguishing culture is an opposite to the nation - a "rational political organization" [6, p. 651]. Thus, the nation-construction ideologies of the multiethnic societies use the elements of ethnicity for "decorative" goals.

Considering the nation as modern phenomenon and the product of political centralization, Smith emphasizes the role of ethnic identity, which is based on the genes and the nature of the people who believe that they are connected with each other by blood [9]. Consequently, the elites of the multicultural countries have a difficult task a) to create a more or less unified nation and b) to help the antagonistic ethnic groups residing in the same country to forget past grievances and hatreds against each other. This opinion contrasts with that of Allahar who argues that the sense of belonging and closeness cannot be mediated by blood only [10]. This is the main idea of civic nationalism, which diminishes or even eliminates the role of ethnic identity in the nationbuilding process. This struggle between the ethnic and civic nationalisms is visible in most of the newly independent states, including Kazakhstan. 


\section{Dilemma of Primordialism and Constructivism}

Two basic schools of ethnicity primordialism and constructivism explain the origins and the patterns of ethnicity in two different ways. For primordialists ethnicity is born "around the sociologically known similarities" such as kinship; they are fixed after construction, and shaped by the conflicts with other neighbouring ethnicities throughout the history of existence [11, p. 1643]. The primordialists claim that individuals are born with one fixed ethnic identity which can withstand human manipulations. Whereas the constructivists claim that the individual may have multiple ethnic identities and it could be edited or changed by the human acts [4]. In other words, each generation of ethnic group is the modified version of the previous one, as the group may experience changes as a result of integration with others [10]. Ethnic borders can be changed in different ways, some groups may merge with others and create a new ethnic group, while others simply split, and the birth of new groups does not necessarily lead to the death of the old groups [2].

The pivotal idea of constructivists is that the identities are always subject to reexamining and redefinition by the members of the ethnic group. When the changes in the repertoire of the ethnic group, or in their perception of themselves occur in a big numbers, this could lead to enormous shifts in the self-definition of the ethnic group. As the self-understanding and self-definition of the group depend on various internal and external factors, the "construction" of the ethnic group could be managed or directed, hastened or slowed down by different players [4].

However, the ethnic groups have a tendency to accentuate some of these patterns in their identification processes and this is especially visible during ethnic conflicts. For instance, as in the case of Chechen war, the distinct ethnic religion could become a salient pattern if the majority of that ethnic group is committed believers. But, on the contrary, in case of conflict between ethnic groups of the same religion, the faith cannot overcome discrepancies that emphasize other patterns of the ethnic group [12].

Similarly, Calhoun underlines the role of language in creating an imagined nation based on ethnicity [13]. Most of the contemporary ethnic conflicts are caused by the claim of the people to defend their right to speak in their mother tongue [14]. At the same time, the commonality of the language does not deter the ethnic groups from antagonism and even genocide against each other as it was clear from an example of Hutus and Tutsis in Rwanda, both of which use Rwanda-Rudi as their native language.

The constructivist theory of ethnicity has more compelling strengths and it is becoming a viable concept, especially in the 21st century with the highest level of integration between nations and ethnic groups. The time, duration and circumstances of the ethnic identity change may vary from country to country, however, even the primordialist scholars acknowledge the fluidity of the ethnic identity alteration processes. The ethnicity is a way of thinking, a "daily plebiscite" as Renan described, and in a globalized world with the high degree of ethnic integration the individuals have a right to choose their own identities [11]. This is consonant with the idea of comparing constructivists with the feminists, who stated that the biology is not destiny, and "primordially-based emotions and sentiments need not be seen as absolute, rigid, and inflexible" [10, p. 203].

\section{Ethnic Identity Change}

Chandra states, that the main idea of politicization of ethnicity is applicable to the groups with "fixed" ethnic identities, and "If ethnic identities are fluid, not fixed, then the other propositions fall through" $[4$, p. 58]. Why some ethnic identities seem to change, while others are static? Perhaps, the most compelling explanation of this is 
given by Nagel [15] and Fearon and Laitin [16]. Fearon and Laitin maintained that the ethnic identity construction process is arranged in three different ways. First, the social and economic processes in the society can make a difference in people's perception of the ethnic boundaries. The one clear example is the development of printing in the era of "print capitalism" [5], in which people, living in different continents felt themselves culturally connected. The second way of identity construction is the "discursive formation of symbolic or cultural systems" with its own specific logic [16, p. 851]. Third, the identity is constructed and edited by the intended actions of individuals and group elites. So, the more salient these processes, the more rapid the identity is changed or reconstructed. Similarly, Nagel argues, that the ethnic identity can be fluid depending on the number of factors, including the individual identification, the informal ascriptions and the official policy of the governments [15]. In the practical part of the paper I will try to use these categories of Nagel to measure the level of "fluidity" of the ethnic identity of Russians.

Historically the nation-states tried to culturally standardize their populations, and building a state and creating an ethnicity are reciprocal processes capable of begetting one another [12]. The ethnic minorities create problems for national elites, as "they communicate their distinctiveness in contexts where this distinctiveness is incompatible with the requirements of the nation-state" $[7$, p. 273]. This is an issue of modern state building: modern statehood since the late 18th century is predicated on the idea the people (the ethnie) coincide with the state. Therefore, minorities were seen as problematic and thus subject to discrimination and/or assimilatory policies. Likewise, Tishkov concludes, that the nation-building processes in the world often driven by "force, will or fortune, but not logic and established rules" [8, p. 641]. So, the standardization of the identities of different ethnic groups residing in the same country was often driven by force and by political power.

However, Gat \& Yakobson admitted that the state's attempt to manipulate over the identity issues didn't succeed. Even the utilization of such manipulating instruments as schools, universal military services and media by the big empirestates could not create a unified nation [12], and the division over the ethnic lines as well as the establishment of the federal state with more or less clear ethnic boundaries was one of the causes disintegrated the Soviet Union and Yugoslavia. Therefore, the assumptions of modernists that the "state building" is the synonym of "nation building" were ultimately wrong. The failed states in Asia and Africa, which were created irrespective to their ethnic boundaries and now experiencing the painful disintegration and war, are another example (ibid).

Then, why is it so difficult to change ethnic identities by force or by political manipulations? Analysing different approaches to the ethnic identity, Anderson suggests that the assimilation theory is the most realistic one, as the cultural and economic globalization is capable of pushing the ethnicity to the sidelines [5].

Chandra names descent as the main constraint in creating synthetic ethnicities or assimilating them to the mainstream group. Furthermore, a complex of matters, such as "history, institutional background, economic factors, ideological factors, social norms, and territorial factors" could play a crucial role in this process [4, p. 17]. In order to distinguish the descent-based groups (primordial ethnic groups) from non-descent-based groups (cosmopolitan groups with less emphasis to ethnic identity) Chandra asks three simple questions (a) the set of ethnic categories that the groups use; b) the difference of these categories from other groups; $c$ ) the membership rules in that group. The most conspicuous is the ethnic categories such as language, history, religion, the strong the identity of that group. The close is the ethnic group to the outsiders, the solid its "immunity" against the assimilating 
manipulations from outside. However, even the descent-based identities could be changed under some circumstances.

"The difference between descentbased identities and non-descent-based identities lies not in whether they change but how.

(1) Change in the repertoire of descentbased attributes that characterize a population.

(2) Change in the "full" repertoire of nominal ethnic identity categories generated by these attributes.

(3) Change in the constraints that define the "operative" repertoire of nominal ethnic identity categories.

(4) Switching of the descent-based attributes of individuals within an existing population repertoire.

(5) Change in the ethnic identity categories activated by individuals through a process of reclassification of attributes from their fixed repertoires" [4, p. 132].

The vast number of factors determines the level of assimilation of the descentbased identities; it includes the assimilation policy of the government, the proximity of the boundary of the alien ethnic group, the openness of the society to cultural integration.

In his classic critique of ethnic groups Horowitz maintained that the ethnic identities could be changed through the duo-direction process of self-definition and the definition by others [2]. Thus, manipulation from outside should be entailed by the internal processes within the ethnic groups, through which they consider the changes in the repertoire of the group. Horowitz also points out the decisive role of the active groups of the society, or so-called "movements of differentiation" who will compete with the "movements of assimilation" in order to maintain the borders of ethnic group and promote the myths and legends about the group's past (ibid). Also, the readiness of the group to the assimilation depends on the level of threat or perceived threat from an alien group [17].

\section{Role of Ethnicity in Conflict}

A large body of literature has focused on the salience of ethnic division as the portent of war [18; 19]. Though the parties involved in the conflict are identifiable, it's not clear why the certain conflicts labelled as "ethnic", as the most conflicts between groups of people are caused by concrete social, cultural or political discrepancies. Cordell and Wolff consider that there is no any single conflict in the world solely based on the ethnicity. "The most important confusion is that ethnic conflicts are about ethnicity - ethnicity is not the ultimate, irreducible source of violent conflict in such cases" [20]. The ethnicity rather can encourage the group to the joint action. Likewise, the ethnic groups in the multicultural society tend to explain its dissatisfaction with the status quo in ethnic terms.

Some theorists treat the ethnic groups as "incipient nations", with an attachment to particular land and a potential to create its own nation under certain circumstances [4]. Therefore, own territory and a "functional differentiation" are two idiosyncratic characteristics of ethnic groups that distinguish them from others [4, p. 58]. Likewise, Horowitz pointed out the ethnic boundaries rather than the content of ethnic ideologies as a source of discord. The countries with two or more indigenous ethnic groups, who claim themselves as the exclusive owners of the land have more chance to be involved in the conflict [2].

The shared myths and memories are essential characteristics of ethnic existence and survival. Smith points out that the nation should possess a recorded history of "golden age", sufferings and wars with enemies, and these memories in the form of folklore could be copied from the titular ethnic group and applied to the whole nation-building process, that he names as "historical ethno-symbolism" [18, p. 14]. By Azar and Gat "a shared history is conducive to the creation of a common identity precisely to the extent that it generates a common culture and a sense of kinship" [12, p. 25]. But these theories do 
not address the question of antagonistic ethnic groups residing in the same country, who are subject to the common nationconstruction process. Can they simply "give up" their ethnic memories if the very idea of their existence is based on the struggle against the next-door ethnic group? The "enormous power of ethnicity" [14] would not allow to do this, as Nikitina has recently reckoned that the attempt to democratize the history is failed in Estonia, because the Estonian nation is constructed on the idea of struggle against Russian colonizers, whereas the ethnic Russian population has a totally opposite view of the history [21].

\section{Conclusion}

Thus, according to ample research on this topic we have seen that theories and concepts of ethnos and nation are often not the same.

Proponents of constructivism argue that it arises because of targeted influence by all ethnic communities, cultures and power elites that have emerged at different stages of human development. Processes such as to the modern state, administrative centralization, statistical data collection, taxation, language standardization, centralized education systems, the creation of military and law enforcement agencies can create or change a nation.

At the highest level of integration between nations and ethnic groups in the $X X I$ century, it can be concluded that the constructivist theory of ethnicity has its own advantages and is becoming a viable concept.

We may now distinguish three multidirectional and mutually contradictory developments in our understanding of the ethnic identity phenomena thanks to the updated literature. First of all, national elites have always attempted to categorize ill-assorted fellow citizens/subjects of their country, eliminating ethnic patterns (language, religion, history, etc.) and either replacing them with the characteristics of the dominant ethnic group or creating artificial supranational entities, regardless of their forms of government. Second, in spite of these unifying acts, empires have been unable to construct a multicultural civic country or minimize the significance of ethnicity for millennia; as a result, ethnicity is the most powerful collective identity that may lead to worldwide conflicts. Third, ethnic identities tend to adapt and change, and different patterns of them may emerge due to various reasons and be altered without the intervention of external teleological forces.

\section{References}

1 Hale H. The Foundations of Ethnic Politics: Separatism of States and Nations in Eurasia and the World // The Journal of Politics.- 2008. - №1 (72). - P. 260-262.

2 Horowitz D. Ethnic groups in conflict. - 2nd edn. University of California Press, Berkeley, CA, 2000. - P. 720

3 Smith A.D. The ethnic origins of nations. - Blackwell, 1987.

4 Chandra K. Constructivist Theories of Ethnic Politics. - Oxford University Press, 2012.

5 Anderson A.B. The Complexity of Ethnic Identities: A Postmodern Reevaluation // Identity.- 2001.- № 1(3).- P. 209-223.

6 Hutchinson J. Ethnicity and modern nations // Ethnic and Racial Studies. - 2000. №4(23). - P. 651-669.

7 Eriksen T.H. Ethnicity versus Nationalism // Journal of Peace Research. - 1991. - №3(28). - P. 263-278.

8 Tishkov V. Forget the 'nation': postnationalist understanding of nationalism // Ethnic and Racial Studies. - 2000. - №4(23). - P. 625-650.

9 Smith A.D. Culture, Community and Territory: The Politics of Ethnicity and Nationalism // International Affairs (Royal Institute of International Affairs 1944). - 1996. - №3(72). - P. 445-458.

10 Allahar A.L. The Politics of Ethnic Identity Construction // Identity. - 2001. - № 1(3).- P. 197-208.

11 Bayar M. Reconsidering primordialism: an alternative approach to the study of ethnicity // Ethnic and Racial Studies. - 2009. - №9(32).P. 1639-1657.

12 Gat A. \& Yakobson A. Nations, The Long History and Deep Roots of Political Ethnicity and Nationalism. - Cambridge University Press, 2012. 
13 Calhoun C. Nationalism and Ethnicity // Annual Review of Sociology. - 1993. - №19. - P. 211-239.

14 Wolff, S. Ethnic Conflict: A Global Prespective. - Oxford, Oxford University Press, 2006.

15 Nagle J. Does Having a Kin State Lessen the Likelihood of Minorities Engaging in Secessionist Mobilization?: An Analysis of the Moderating Influence of Kin States // Nationalism and Ethnic Politics. - 2013. - №3(19). - P. 287-309.

16 Fearon J.D. \& Laitin D.D. Violence and the Social Construction of Ethnic Identity // International Organization.- 2000. - №4(54). P. 845-877.
17 Poppe E. \& Hagendoorn L. Titular Identification of Russians in Former Soviet Republics // Europe-Asia Studies. -2003.- №5(55). - P. 771-787.

18 Smith A.D. When is a Nation // Geopolitics. - 2002. - №2(7). - P. 5-32.

19 Brubaker R. Nationalizing States in the Old 'New Europe' - and the New // Ethnic and Racial Studies.- 1996. - №2 (19). - P. 411-437.

20 Cordell K. \& Wolff S. Ethnic Conflict: Causes, Consequences and Responses // Journal of Peace Research №1 (48). - P. 127-135

21 Nikitina Y. Legacy and Responsibility in the Post-Soviet Space. // PONARS Eurasia, 2014. - (202). - P. 14-18.

\section{INFORMATION ABOUT AUTHORS}

Doszhan Kaliyev

Aimar Ventsel

Досжан Сагидолдаевич Калиев

Аймар Вентсель

Досжан Сагидолдаевич Калиев

Аймар Вентсель
PhD student, Al-Farabi Kazakh National University, Almaty, Kazakhstan

Professor, Senior Researcher, University of Tartu, Tartu, Estonia

PhD докторант, Әл-Фараби атындағы Қазақ ұлттық университеті, Алматы, Қазақстан

Профессор, аға ғылыми қызметкер, Тарту университеті, Тарту, Эстония

PhD докторант, Казахский национальный университет имени аль-Фараби, Алматы, Казахстан

профессор, старший научный сотрудник, Тартуский университет, Тарту, Эстония 